\title{
Dig for victory! Anti-consumerism, austerity, and new historical subjectivities
}

\begin{abstract}
In recent years, austerity-related discourses have become a popular means of imagining and promoting more sustainable living. This article situates the reemergence of the slogan 'dig for victory' in the wider discursive formation of 'anticonsumerism', and explores the relationship between the 'defetishizing' qualities of commodity histories and the constitution of ethico-political consuming subjects. Following Laclau's notion that a conversion of subjectivity results from persuasion, I suggest that the persuasiveness of 'dig for victory' lies in its insistence upon historical solutions to today's problems. The discourse seems to consolidate the dominanthegemonic 'myth of the home front', yet 'dig for victory' also appears to have the capacity to render certain radical ideas, such as operating outside of the capitalist commodity system, unthreatening and even appealing. I explain why this case study points to an urgent need to rethink the historical as a resource for the constitution of radical collective projects and agents.
\end{abstract}

\section{Keywords}

austerity; anti-consumerism; environmentalism; history; home front; sustainability

\section{Introduction}

In the summer of 2007 the Imperial War Museum ran an allotment project with The Royal Parks, setting up a 'victory garden' in St James's Park, London. The rationale for the project rested on a perceived relationship between the priorities of Britain during the Second World War years, as epitomized by the 'dig for victory' campaign, and the 'things that we are concerned about today - having access to fresh healthy food, being active and living sustainably' (Imperial War Museum, 2008: 1). This project can be situated in the context of the emergence, at around the same time, of 'austerity' as a distinctive discursive formation. The idea that we are living in a new 'age of austerity' has become widespread in British culture, particularly since the May 2010 election. Austerity discourses are extremely diverse; they serve a wide range of agendas, and are mobilized by an array of social actors. They can be characterized, however, by their tendency to articulate concerns about the environment manifested in the incorporation of notions of thrift, frugality, sustainability, being 'green', waste, and so on - to anxieties about the economy. This articulation of the 
environmental to the economic takes place, in austerity discourses, via the notion that there is an analogy to be drawn between today's straightened times and Britain in the first age of austerity, a period which incorporates the Second World War and post-war years of 1945-1955. Texts in which austerity discourses are mobilized ranging from gift items, coffee table books and exhibitions to press articles, television programmes, and advertising - tend to explicitly evoke the styles and iconography of the home front and post-war austerity years, typically by employing the modernist typography of Ministry of Information campaign posters, or by incorporating clips from period films, or black-and-white photographs of life in 'ration book' Britain. A particular feature of austerity discourses has been the extensive mobilization of key slogans deriving from the state policies, public information and propaganda of the home front. The most popular of these slogans - those that have proved most resonant, in the current conjuncture - are 'dig for victory', 'make do and mend', and 'keep calm and carry on'. Of the three, 'dig for victory' has been selected as a focus of this article because of the particular uses to which it has been put. First articulated to debates about land use and the environment by grassroots activist group The Land Is Ours in the late nineties (Crouch and Parker, 2003: 403), 'dig for victory' has since been taken up in a wide variety of contexts related to environmental and anticonsumerist politics, which are the focus of this article.

Anti-consumerism has been described as 'a widening popular discourse on the problems of contemporary consumerism' which can be traced 'in a variety of popular spheres rather than simply through activism or policy'. Anti-consumerist practices 'resonate with each other across their shared regard for the consumer market as an obstruction to some other ethical, moral, political, social or cultural objective' (Binkley and Littler, 2008: 519-20, 524). 'Dig for victory' seems to fit these definitions: in recommending a particular solution to a problematized consumer market, the discourse provides an alternative vision of land use and proposes that producing your own food is a way of becoming an ethical consumer-cum-patriotic subject. Along with cognate slogans such as 'make do and mend', 'dig for victory' can thus be seen as connecting and contributing to the discursive formation of anti-consumerism, while resonating at the same time with other projects and movements. 'Dig for victory' has a relationship to the organic movement, for instance, though it is not a discourse of exclusive organicism (see Hickman, 2008a). It is also connected to the 'art and ecology' movements of the late 1960s to early 1980s, which are currently enjoying a revival in the UK and the US (Norman, 2007; Shaw, 2009), but it is certainly not restricted to the art world; lifestyle television has also been an important 
site for this discourse (see for example Digging for Victory, 2007). Different agendas have been linked via the discourse: in the US context, a city-funded urban agricultural project organized the planting of a sizeable 'victory garden' in the centre of San Francisco for a 'slow food' festival in 2008 (Franceschini, 2008). Because anti-consumerism resonates with a range of existing projects, its politics cannot be taken for granted (Binkley and Littler, 2008: 524-5). This problem extends to 'dig for victory'. The act of imagining a historical precedent for the present conjuncture has undoubtedly opened up a space in which some of today's most critical, and elsewhere disconnected, anxieties and demands can be linked together. Through a circumscribed and unthreatening version of anti-consumerism - declining shopbought vegetables in favour of growing your own - 'dig for victory' engages with the challenge of encouraging people (particularly, although not exclusively, middle-class women) to perceive their anxieties and concerns about the environment, food production, and social inequalities as shared by other people. Where else, in contemporary popular culture, do we find a discourse that links concerns about 'food miles' to questions about quality of life, ideas about nutrition and healthy eating to the demand for land in common, and a valorization of social interaction to the concept of sustainability? At the same time, of course, this discourse - along with other austerity discourses - is in particular danger of being 'claimed back' by conservative, reactionary and protectionist projects because of its dependence upon elements of an emphatically nationalist version of history. In the British context, where gardening has long been regarded as a 'distinctively national virtue' (Samuel, 1989: xxv), a 'victory garden' has been planted in the grounds of Buckingham Palace (Davies, 2009). Moreover, the idea that we are living in a new 'age of austerity' has proved easily articulable to Conservative Party policy (Cameron, 2009) and to the current Coalition Government's programme of cuts; these developments arguably evidence the way in which the 'givenness of the historical terrain' (Hall, 1996: 42) inflects these symbolic resources.

It might be argued that if the politics of 'dig for victory' - jeopardized by its rhetoric of nationalism - is so volatile and uncertain, the transformative potential of this field of discourse is not worth exploring. If, in a new era of mass unemployment, the terrain of politics is likely to shift away from environmental and anti-consumerist issues, why concern oneself with a set of symbolic resources which seem to have had the most purchase, in terms of radical subject constitution, in a context already superseded? But if subject constitution is always 'sticky', always 'carries within it elements from past encounters' (Johnson et al. 2004: 262), it follows that apparently compromised 
discourses such as this demand our critical attention. Just as the character and priorities of environmental and anti-consumerist politics are certainly set to change, any developing political movement will already be marked by the debates they have played a part in structuring and shaping. The 'austerity' frame is critical to evaluate precisely because it is one of the dominant discourses through which the conjunction of economic and environmental 'crisis' is being - and will continue to be - thought, imagined and lived. I want, then, to suggest that the challenge is to attempt to recognize the 'radical potential in emergent cultural tendencies' (Gilbert, 2008: 130) without prescribing in advance the resources upon which these tendencies might draw. In this article, I take the injunction to 'dig for victory' as a starting point for a consideration of the place of historicity in environmental and anti-consumerist politics, arguing that the popularization of this discourse points up the need to rethink theorizations of the relationship between 'the historical' and ethico-political subject constitution. Using the example of 'dig for victory' and other discourses about the environmental and social impacts of food production and consumption, I explore how we might theorize the function of historicity as a discursive element in processes of subject constitution.

\section{Memory, history and subjectivity}

I want to begin by reflecting on the reasons why we might assume that austerity discourses are likely to be politically conservative in nature, and unlikely to encourage a progressive politics. These assumptions are informed, I suggest, by the roles attributed to the historical in longstanding Marxist and left-political theorizations of radical subject constitution. The discourse of 'digging for victory' serves, in fact, to exemplify the various ways in which historical resources have been construed, from a left-political perspective, as obstacles to radical subject constitution. To begin with, the use made of the past in this discourse is particularly instrumental, as exemplified in the way that 'dig for victory' has been referenced in the press:

It's hard not to draw parallels with the Dig for Victory campaign during the second world war, when public land was given over to communities to grow their own food. With growing talk about how nations need to be much more selfsufficient in food, and therefore less vulnerable to the vagaries of global food prices, are we now re-entering an age when land once again becomes a highly prized - and much- 
needed - resource for all members of the community?

(Hickman, 2008b).

While the new 'dig for victory' discourse clearly has a historical referent, it is not really about this past at all. The 'myth of the home front', characterized, as one historian puts it, 'by universal sacrifice, egalitarianism, and common purpose' (Zweiniger-Bargielowska, 2000: 2), but also by its commanding slogans and eyecatching typography, is unapologetically put to work for present-day needs. Such a decontextualized mobilization of the styles and surfaces of the past inevitably calls to mind Fredric Jameson's analysis of historicity in postmodernism. For Jameson, the pop-historical, 'retro' cultural products of late capitalism are indicative of a situation 'in which we are condemned to seek History by way of our own pop images and simulacra of that history, which remains forever out of reach' (Jameson, 1991: 25). It is postmodernism's 'incredible ability to plunder history and absorb whatever it finds there as some aspect of the present' that is widely criticized in Marxist analyses of the period (Harvey, 1989: 54). The objection, of course, is to a historicity construed as a barrier to the constitution of the working class as a collective agent of social change. Lacking the faculty of a properly Marxist historicity, the postmodern subject is lost, on this account, in a 'mesmerized contemplation of a schizophrenic present' (Jameson, 1991: xii). It is also strikingly obvious that 'dig for victory' mobilizes a dominant-hegemonic narrative of British history. There is little sense in which this narrative can be claimed as a radical or marginalized 'counter-memory' (Foucault, 1975); on the contrary, it appears to confirm that which is regarded as common sense, to strip history of its contingency, an attribute widely seen as characteristic of ideology (see Wright, 1985: 69; Bromley, 1988: 12). The nature of the 'struggle' that is recovered in 'dig for victory' is certainly not of the kind privileged in left-political historiography: the historical representations in question here cannot readily be construed as communicating the 'daily oppressions and the struggle against them' faced by 'typical' subject positions within dominant social relations (Popular Memory Group, 1982: 239). ${ }^{1}$ And it is also worth noting that 'dig for victory' poses an obvious problem for those who maintain that a link between 'experience' and 'memory' is critical to the constitution of subjects, radical or otherwise: the thirty-something consumers most responsive to austerity discourses don't 'remember' the war.

If austerity discourses serve to exemplify the various ways in which historical resources have been construed - from a Marxist, left-political perspective - as blocking radical subject constitution, poststructuralist, post-Marxist insights have 
done much to point up the complexity, plurality, and contingency of such processes. These contemporary theories of subjectivity ought to provide us with a means of engaging differently with the historical; a means of explaining why, for instance, 'dig for victory' and other austerity discourses have indeed found the most purchase with that generation of consumers who have no 'memory' of the wartime years. One of the objectives in Ernesto Laclau and Chantal Mouffe's Hegemony and Socialist Strategy is to break with the notion 'deeply inherent' to Marxist theory that the movement of history is determined by underlying and ultimately determinable laws, and that one 'sector', the working class, has a particular claim on knowledge of those laws (Laclau and Mouffe, 2001: 4, 56). Laclau and Mouffe reject then 'the idea of a perfectly unified and homogenous agent' of historical change (2001: 84), and this insight problematizes any attempt to map subjectivities present to subjectivities past, to assume their continuity or identity. Because articulatory force is construed as 'constituted in the general field of discursivity' rather than in relation to an idea of a 'transcendental or originative subject' (2001: 114), there is no recourse in Laclau and Mouffe's text to a concept of 'memory'. Along with the category of 'experience' and various other notions relating to the human, this concept has been conceived more generally in poststructuralist theory as 'a product, not an explanation', and therefore as a problematic basis for 'epistemological or political claims' (Johnson et al., 2004: 257). Laclau and Mouffe have contributed to the widely-held position that 'forms of subjectivity are produced historically and change with shifts in the wide range of discursive fields which constitute them' (Weedon, 1987: 33).

Why, then, do uses of the past deemed problematic in Marxist, left-political theorizations - instrumentalization, decontextualization, the mobilization of dominanthegemonic narratives rather than 'marginal' struggles, the breaking of a link between experience and memory - remain suspicious to us now? It ought, from a poststructuralist perspective, to be possible to consider the contribution 'dig for victory' might make to processes of radical subject constitution. The fact that 'dig for victory' interpellates subjects who have no memory of the war should not in itself be a reason to rule out this discourse's transformative potential, nor indeed should the fact that it does not revive the history of radical struggles past, but rather re-presents the mythologized activities of the home front. As Bill Readings noted some time ago, however, the implications of poststructuralist interventions for the left-political orientation towards the past have never been adequately acknowledged (Readings, 1991: 60). Where scholars remain engaged with theorizing the place of the past in constituting the political subjectivities of the present, the testimonial of the recognized 
subordinate continues to be seen as an important means of producing social and political change. It appears to be difficult for contemporary theorists to think about the past as a resource for the formation of progressive political alliances in the present without falling back on established left-political distinctions between 'radical' and 'conservative' histories, or 'hegemonic' and 'counter-hegemonic' narratives, as if the identity of radical subjects past and present can be assumed, or as if that which we have come to recognize as 'radical' or 'counter-hegemonic' remains an 'element', a 'difference that is not [has not yet been] discursively articulated' (Laclau and Mouffe, 2001: 105). In other words, those seeking to identify processes that might constitute 'radical subjects' or encourage 'radical action' find it difficult to think beyond certain highly-thematized versions of the radical. In relation to notions of urban agriculture and sustainability, for instance, they'd prefer the horticulturalist to look like one of Gerrard Winstanley's Diggers (or their 1960s, counter-cultural incarnation ${ }^{1}$ ) than a wartime allotment-tending housewife.

While poststructuralist, post-Marxist perspectives are descriptively helpful when considered in relation to a specific discourse such as 'dig for victory', there remain, then, many issues to be worked through vis-à-vis the role accorded to 'historical' resources in contemporary models of subject constitution. It is to this task that I address myself in the rest of this article. Historical resources are critical to the translation and dissemination of environmental and anti-consumerist claims and demands in the mainstream media. In the current moment it has become more urgent than ever to address the question of the relationship between the historicity of discursive practice and the constitution of emergent subjectivities, and the kinds of discursive resources which may or may not constitute 'radical' subjectivities. In what follows I will continue to draw on Laclau and Mouffe's model of subject constitution, derived from their theory of hegemony (2001). It is worth briefly clarifying several aspects of this model here. Laclau and Mouffe are primarily interested in describing processes of hegemony and the means through which subjects are 'produced' in and through these processes. They use the term 'discourse' to refer to both linguistic and behavioural aspects of social practice, rather than regarding the latter as 'nondiscursive' (Laclau and Mouffe, 2001: 107). The practice of 'allotment gardening' is, for instance, discursive, in that it is only meaningful to those subjects perpetuating and/or acknowledging that practice in relation to the way in which 'allotment gardening' has been constituted through discourse. Moreover, the practice itself signifies - it is discursive in that it secures or modifies available meanings of 'allotment gardening'. Laclau and Mouffe do not allow us, then, to fall back on a 
reductive distinction between 'discourse' on the one hand and what might be described as 'concrete political practice' on the other. They help us to understand how subjects come - through discursive processes - to be persuaded of the validity of certain positions, and thus to be transformed as subjects, rather than to explain how subjects come to perform certain acts. It is very important to emphasize Laclau and Mouffe's understanding of the contingency of these processes; that it is not possible, in other words, to anticipate in advance the relationship between emergent discourses and subjectivities. As they put it, "[s]truggles derive their meaning from their hegemonic articulation, and their progressive character - from a socialist point of view - is not assured in advance' (Laclau and Mouffe, 2001: 71). What is possible is to explore new ways of evaluating discursive practice in order to identify formations that tend towards the production of new hegemonies around, for instance, a sustainability agenda. It is my suggestion that the role of historicity in shaping these tendencies requires much more careful attention. That is the reason why this article will go on to consider the persuasiveness of histories and historical resources we are accustomed, from a left-political point of view, to thinking of as deeply problematic, while recognizing that there are many obstacles to their actualization as resources just as there are many obstacles to mobilizing so-called 'radical' narratives and histories.

Theorists researching 'anti-consumerist' discourses and movements have, in recent years, been particularly attentive to the contingency of subject constitution. In the next section of this article I use a popular non-fiction account of food production and consumption practices, Michael Pollan's The Omnivore's Dilemma (2006), to consider how the relationship between knowledge about commodities' histories and 'ethical consumption' has been modelled in contemporary theoretical work on consumer subjectivities. I go on to make a case for recognizing historicity as a critical element in the persuasiveness of commodity histories for certain constituencies, and, returning to the example of 'dig for victory', I re-evaluate this discourse's hegemonizing potential in a context in which the concept of austerity is being used to legitimate an attack on the welfare state.

\section{Commodity histories: disclosure and persuasion}

One of the elements of 'dig for victory' that might be assumed to be problematic from a left-political point of view is that the subjects of this discourse are clearly being interpellated as consumers, rather than as producers or workers. Studies of 'anticonsumerism' offer a valuable context in which to rethink some of the orthodoxies 
I've identified, because they have come to consider the consumer (rather than the worker, or the subaltern) as a site of political agency (Barnett, Littler and Soper, 2005; Littler, 2009; Soper, 2009). ${ }^{2}$ One way of describing how 'dig for victory' works in terms of subject constitution is to suggest that it offers a schema of the contemporary agricultural system in terms legible to the consumer. Scholars of anticonsumerism have been particularly interested in these schemata and their role in transforming subjects. Information about commodity production is made available to consumers in a range of contexts, and takes a number of forms. Commodities can carry simple descriptions of the route the product has taken from producer to consumer, a strategy associated with 'fair trade' foodstuffs, while agents external to the process of producing consumables - film-makers, artists, journalists, curators also generate mappings of, and narratives about, commodity production. A developing and popular 'suspicion of the commodity', one of the tendencies regarded as characteristic of the phenomenon of anti-consumerism (Binkley and Littler, 2008: 521), has encouraged debate about these strategies of commodity 'defetishization' (Littler, 2005; Cook et al., 2007). There is general agreement that commodity 'geographies' or 'histories' have a relationship to consumers' consciousness of relations of production in contemporary capitalism. As Littler puts it, they enfold 'a particular kind of story about existing social relations and future possibilities' (Littler, 2009: 43). The notion of commodity (de)fetishization has taken 'centre stage' in these debates (Cook et al., 2007: 1115), providing a way of conceptualizing the processes through which consumers are constituted as ethico-political subjects. Commodity geographies and histories are seen, in other words, as both reflective and productive of consumers who are conscious of the negative social and environmental impacts of over-consumption. The current recourse to a concept of commodity fetishism draws on the idea that the commodity form instantiates a problematic spatial (Barnett et al., 2005: 24) and/or temporal separation between social actors, a separation often construed in Marxist theory in terms of the anamnesic capacities of the consuming subject. For Jameson, the commodity form functions to 'obliterate the signs of work on the product in order to make it easier for us to forget the class structure which is its organizational framework' (Jameson, 1971: 408). What differentiates today's use of the concept is of course the fact that the 'signs of work' transposed in Marxist theory to the commodity form are considered legible, under certain conditions, on the part of the consumer, and potentially constitutive of 'remembering' ethico-political subjectivities. For the purposes of this article, both the nature of this legibility and the processes through which defetishization might contribute to a transformation of the consuming subject need to be scrutinized further. 
The Omnivore's Dilemma (2006), a best-selling book by the North American journalist and food writer Michael Pollan, ${ }^{3}$ offers an example of the kinds of defetishizing strategies that are being pursued by social actors in his position. The book promises a 'natural history of four meals', provided via the author's description of a series of 'adventures' into the 'food chains that sustain us, all the way from the earth to the plate' (Pollan, 2006: 6). The fourth meal, which Pollan prepares from ingredients he has hunted, foraged, and gathered himself, is presented as the 'Perfect Meal': it gives the author 'the opportunity [...] to eat in full consciousness of everything involved in feeding myself: For once, I was able to pay the full karmic price of a meal' (2006: 9). Here ethical consumption is explicitly linked to a consciousness of the processes of food production, described in relation to this particular meal's journey of discovery as 'full' consciousness because Pollan has actually 'produced' the ingredients involved, rather than simply visiting the farms and processing plants in which the ingredients for his other meals were manufactured. Producing food brings Pollan that crucial step closer to the kind of knowledge required to consume ethically. The implicitly ethical status of Pollan's own intervention, in the form of the published descriptions of the journeys into the 'historical-geographical "careers"' (Barnett et al., 2005: 25) of his chosen meals, is of course related to this privileging of knowledge about production. It might not be quite as consciousness-raising to read about someone else's experiences of hunting and gathering, but it's the next best thing, given that it is unlikely you're going to pursue these activities yourself.

The idea that there is a relationship between the provision of knowledge about the commodity chain and consumer subjectivity has neither been embraced uncritically by scholars of anti-consumerism, nor seen as unproblematic. The discourses of 'authenticity' that often go hand-in-hand with those of defetishization can, it is argued, consolidate middle-class consumers' self-interest and cater to consumption practices which 'produce exclusion' (Zukin, 2008: 735). It is acknowledged that the defetishizing narratives provided by fair trade products and campaigns may have a transformative potential, but the diversity of the audiences they address and the range of their possible symbolic meanings and effects must be taken into account (Moor and Littler, 2008: 702; Littler, 2009: 45). Furthermore, the signifying tropes and practices associated with defetishization can themselves be fetishized (Moor and Littler, 2008: 720; Sassatelli, 2009: 38) and used to perpetuate the interests of corporate capital. In the field of cultural studies, at least, there is then evidence of 
agreement with the argument offered by Clive Barnett et al. that ethical consumption practices 'are part of broader projects which aim to transform self-understandings of wants, needs, desires, and satisfactions'. There is more to ethico-political subject constitution - to becoming an 'ethical consumer' - than the provision and possession of 'coherent knowledge' or information (Barnett et al., 2005: 32, 26). There are also, to put it simply, issues of 'voice, message and audience' (Cook et al., 2007: 1118).

Pollan's text offers a clear exemplification of the distinction pursued in these discussions. I've suggested that The Omnivore's Dilemma implicitly makes the case for itself as an ethico-political intervention, a claim which rests on Pollan's adoption of what we can now describe as the 'informational model' of political rhetoric (Barnett et al., 2005: 42). 'One of the key innovations of organic food', he argues, 'was to allow some more information to pass along the food chain between the producer and the consumer - an implicit snatch of narrative' (Pollan, 2006: 136). However, Pollan conveys far more unease about such a model when it comes to the commodity histories presented by retailers - and in particular organic supermarkets - for the benefit of their consumers. The purer, cleaner, more truthful information offered by the early organic movement has, Pollan suggests, metamorphosed into a discourse that is both more generic and more emotive. He offers a rather insightful reading of it:

Taken as a whole, the story on offer in Whole Foods is a pastoral narrative in which farm animals live much as they did in the books we read as children, and our fruits and vegetables grow in well-composted soils in small farms [...]. "Organic" on the label conjures up a rich narrative, even if it is the consumer who fills in most of the details, supplying the hero (American Family Farmer), the villain (Agribusinessman), and the literary genre, which l've come to think of as Supermarket Pastoral. [...] Supermarket Pastoral is a most seductive literary form, beguiling enough to survive in the face of a great many discomfiting facts. I suspect that's because it gratifies some of our deepest, oldest longings, not merely for safe food, but for a connection to the earth (2006: 137).

While Pollan is evidently conscious of the powerful rhetoric at work here, and gestures in the direction of some compelling reasons why consumers might be 
persuaded by this pastoral discourse, he is unable to develop these conjectures any further. Pollan's response to the problematic of 'Supermarket Pastoral', which rests on the informational model, is to question how adequately the farms that are now part of the 'industrial organic' system 'match the stories told about them'. 'Just how well', he asks, 'does Supermarket Pastoral hold up under close reading and journalistic scrutiny?' (2006: 137). Pollan fails to follow through the logic of his own argument: the 'real' organic movement failed, even though it provided 'truthful' information; the industrial system is effective and successful, and provides seductive narratives. The limitations of the informational model for a theorization of the constitution of ethico-political subjectivity are thus revealed in the paradox Pollan confronts: he wants consumers to know about commodity histories, but he objects to the wrong kinds of histories - the kind that is exemplified by 'Supermarket Pastoral'.

The observation that can be developed out of an evaluation of the informational model of political rhetoric - or what Jeremy Gilbert, making a related critique of the 'activist imaginary', describes as the 'politics of disclosure' - is that information in itself (if such a thing could be said to exist) is never going to be enough to motivate political intervention. What is critical, Gilbert argues, is 'the question of how you persuade others to agree with you' (Gilbert, 2008: 206, 219). The point that persuasion is not a matter of 'algorithmic demonstration' - of 'proof' - but rather an activity with room for a 'great deal of subjective variation' is made quite clearly by Laclau. In other words, 'what persuades one person will not succeed in persuading somebody else':

It is for this reason that persuasion is always, to some extent, a conversion: I accept an argument, I am convinced that this or that is the case - that subjective moment of acquiescence is essential to persuasion. It is because of that, that we can speak of the force of persuasion. (Laclau, 1999: 97)

I will return to this notion of the 'force of persuasion' in a moment, but for now I want to suggest that the challenges revealed in Pollan's account of 'Supermarket Pastoral' are threefold. It is, first of all, imperative to develop the thoughts Pollan expresses about the form and content of the discourse at work here. When Pollan notes that 'the longer I shopped in Whole Foods, the more I thought that this is a place where the skills of a literary critic might come in handy' (Pollan, 2006: 136), he's thinking along the right lines: what is critical for an analysis of Pollan's example of the 
discursive strategies used to sell organic milk is both a recognition that we are dealing here with the genre of the pastoral, and an appreciation of the history of this genre (Williams, 1975) which may begin to hep us understand, in less essentializing terms, the appeal of happy cows for the contemporary consumer. 'Supermarket Pastoral' tells a story about organic milk production through the genre of the pastoral, recognizable to Pollan via the 'books we read as children'. But the pastoral scene he so fluently describes will only engage those constituencies who possess a familiarity with the genre, and who perceive their interests as resonant or coincidental with its contemporary meanings. As Pollan also notes, 'it is the consumer who fills in most of the details'; it is not just the content and form of the narratives on offer that must be historicized, but also the structures of feeling inhabited by the constituencies who shop in organic supermarkets and are interpellated by this discourse. We need then to understand the appeal of particular stories for certain constituencies. Finally, Pollan's assumption that the subjects of 'Supermarket Pastoral' are being persuaded to buy 'industrial organic' milk leads to a very literal interpretation of the forms of action that might arise from a trip to Whole Foods. The question of the relationship between the persuasiveness of particular discursive interventions and what, exactly, 'converted' subjects might do is a complex one. I suggest that we could think about what is at stake in this scenario in terms of the contribution 'Supermarket Pastoral' might make to consumers' resources for imagining 'existing social relations and future possibilities', regardless of whether or not that carton of milk is purchased. From Laclau's perspective, what is significant here in terms of subject constitution is the 'moment of acquiescence', the moment when the subject is persuaded of a compelling alternative to the status quo - is converted or transformed through persuasion - and thus becomes open to intervening in the world in ways that would otherwise be closed down, or (and this outcome is equally as significant) capable of conceiving of already habitual actions in new ways. 'Supermarket Pastoral' may be the first step towards practices that might be more readily acknowledged by Pollan or other activists - as forms of radical environmentalism.

\section{Historicity and the 'force of persuasion'}

I have been using the concept of the commodity history as a means of exploring the processes through which anti-consumerist, environmental subjectivities might be constituted through the 'signs of work' made available in commodities such a carton of milk or a book such as The Omnivore's Dilemma. The notion of a commodity history refers to a defetishizing narrative of that commodity's production, but as I have wanted to suggest, not only is it extremely limiting to think of these narratives 
as purely informational, it is also disingenuous; stories about commodity chains can only be told via the bank of images, discourses and symbols we have developed to understand how the production of commodities in capitalism happens.

Representations of the sweatshop (Moor and Littler, 2008), the organic farm, the cattle ranch, and the cornfield belong in turn to specific histories and geographies: colonial, charitable, liberal, socialist, scientific. Reflection on commodity histories necessarily leads, then, to a consideration of the historicity of discourse, and indeed of the histories of groups and nations. In order to return to my main example, the discourse of 'digging for victory', I would like to extend my discussion to the more expansive range of stories that are told about the social-economic relations of agricultural production. 'Dig for victory' is a resonant discourse not because it reveals the 'truth' about industrialized food production, but because it communicates a meaningful figuration of the relations between food production and consumption and of their environmental and social impacts. Importantly, however, it does so via the invention of a historical precedent, by foregrounding the historicity of the solutions it presents and recommends.

I want now to turn to a consideration of the nature of this historicity and its relationship to the conversion of subjectivity that results, Laclau suggests, from persuasion. Hegemony theory is of course one of the frameworks through which 'persuasiveness' is identified, meaning here the 'common-sense' quality of particular discourses, symbols, narratives, and indeed histories. As I've already suggested, hegemonic, 'common-sense' stories about the past are not usually deemed an appropriate resource for the pursuit of socially progressive demands, while in contrast 'radical' histories are assumed to be critical to left cultural politics. The enduring appeal of the marginalized narrative as bearer of persuasive force can be demonstrated by turning to recent critical work on the historical resources mobilized by land use campaigners. In one of the few attempts to address theoretically the instability of the distinction between 'hegemonic' and 'counter-hegemonic' or 'conservative' and 'radical' resources, David Crouch and Gavin Parker note that there has been little attention paid to the possibilities of 'deploying heritage oppositionally' (Crouch and Parker, 2003: 398). Drawing on two case studies related to the actions of the organization The Land Is Ours, they make the case for campaigners' use of 'heritage' as a means of rendering radical demands credible and palatable. ${ }^{4}$ Heritage, they argue, can serve as a 'legitimising discourse': it can be used to 'soften and appeal to audiences that view heritage as benign or somnambulant' (Crouch and Parker, 2003: 405). It is notable, however, that Crouch 
and Parker still require a notion of the 'alternative' or 'marginalized' (as distinct from the hegemonic) to identify that which provides the 'content' of the radical message: the historical demands of Winstanley's Diggers remain that which must be 'wrapped into notions of heritage' (2003: 396), the latter merely providing the attractive packaging of the message in question. In the current conjuncture, the 'heritagized' styles and surfaces of austerity, as exemplified in the discourse of 'dig for victory', do seem to have the capacity to link together various critical, and otherwise disconnected, anxieties and concerns, and thus potentially to serve as a resource for the conversion of consuming subjects. I contend that histories associated with longstanding hegemonies - such as the myth of the home front - could serve as a means of legitimizing and justifying socially progressive demands, yet 'radical' histories continue to be fetishized as critical to the production of social change and the transformation of subjectivities. This is astonishing when one reflects on the extent to which the histories of radical subjects are regularly co-opted to neo-liberal agendas (see Pitcher, in this issue). My argument can be expressed differently by reiterating an earlier point: the kinds of stories that need to be told about commodity chains are not those that are more truthful, more disclosive, than those already on offer. The narratives and discourses we urgently require are those that resonate with constituencies who need to be persuaded of the legitimacy of the environmental and social demands in question, and specifically with the way that those constituencies presently construe their interests. 'Dominant-hegemonic' history is one resource for such narratives, precisely because it is already available, already common sense.

In order to recognize this possibility, we need however to understand hegemony as 'a type of relationship which can operate in many different kinds of context', rather than a fixed structure or 'a particular location in the topology of the social' (Gilbert, 2008: 219). It follows that neither 'hegemonic' nor 'marginal' histories are persuasive in themselves: a solution or practice that is historical doesn't necessarily have authority. The persuasiveness of 'dig for victory' must be seen as related to the way in which the challenge this discourse takes up has already been constituted. Global climate change has been established as a problem without historical precedent, so the emergence of explicitly historical, austerity-style solutions to this problem has a particular rhetorical force. Representations and discourses that seem to have a historical referent are not, then, a special category of signifying practice. It is rather the case that all signifying practices are historical, in the sense that they are constituted in history; this 'historicity' is an element that can be foregrounded or otherwise, and can have a range of effects. The challenge is to be able to identify the 
formal features that serve to signal what we might call authoritative historicity in any given conjuncture, and to be able to describe the extent to which such a historicity may continue to shore up social inequalities established in past hegemonies, even as radical demands are also achieved.

\section{'Dig for victory' and 'radical' subjectivity}

In an episode broadcast in the UK in October 2008, the popular Channel 4 programme River Cottage Autumn announced an initiative to make more land available for growing vegetables. According to the narrative presented in the programme, the idea for this 'landshare' project came from a grassroots scheme already underway in the 'Transition Town' of Totnes in Devon: we see the show's presenter, Hugh Fearnley-Whittingstall, visit a woman who has negotiated the use of a small plot in her neighbour's garden in exchange for a share of the produce. The River Cottage 'landshare' initiative is intended, Fearnley-Whittingstall explains, to facilitate and extend such arrangements. Significantly, this section of the episode makes use of a long clip from the 1942 film made by the Ministries of Food and Agriculture to promote the original 'dig for victory' campaign. The conversion of a marginal ambition, limited to the tiny numbers of people who live in Transition Towns, into an idea palatable to much broader constituencies clearly depends here on the use of the symbolic resources of the Second World War and the myth of home front. It goes without saying that the chain of equivalence being constructed in this text has its problems. This article has focused on subject positions and structures of feeling most readily occupied by white middle-class female consumers in the affluent West; the classed, raced and gendered nature of austerity discourses is worthy of a separate study in itself. In the example I've just discussed, the prospect of such landshare arrangements tending towards a model of feudalistic patronage, essentially still based on private ownership for some and land dispossession for others, is quite evident. Moreover, as I explained earlier in this article, the emphatically nationalistic version of history on which austerity discourses depend has led them to be appropriated - in the UK context - by conservative projects, and notably by the current Coalition Government. It is arguably the case that in establishing a connection between notions of sustainability and thrift, the popularization of slogans such as 'dig for victory' and 'make do and mend' has served to enable the current, dominant articulation of the notion of austerity to an argument about the morality and necessity of welfare cuts, and to a critique of the Labour government's spending practices. The broader politics of the new austerity are thus complex and conflictual, and remain a site of struggle. The tendencies and 
problematics I have identified set limitations on the universalizing potential of austerity discourses, while the frame of 'wartime crisis' in which collective solidarity is being invoked may place limits on their longevity.

At the same time, however, River Cottage Autumn clearly shows how the discourse of 'dig for victory' can work to render certain radical ideas (for instance, the notion of holding land in common, or of operating outside of the capitalist commodity system) unthreatening, and to persuade more people that such arrangements are both possible and likely to benefit them. While for all the reasons I have just suggested River Cottage might not represent the ideal media text for instituting radical environmental change, it makes use of some very persuasive ideas that seem to be ignored in prevailing models of activism. I've already explained that through recourse to historical precedent this discourse offers an intelligible figuration of the environmental and social impacts of food production and consumption. The episode demonstrates that this discourse can also describe an attainable subject-position for the interpellated consumer. 'Dig for victory' offers, in fact, a fantasy of the elision of the distinction between producer and consumer, manifest in the person of the selfsufficient - yet community-oriented - digger (as does the emphasis on 'making and doing' in austerity discourses more generally). As I have already suggested, it might be argued that 'sustainability' and other environmental concerns will have less of a presence in the radical politics of the next few years. Relatedly, there is a strong case for arguing that socially regressive uses of the concept of austerity - such as those in evidence since the May 2010 election - will undermine the opportunities that I have described. I want to insist, however, that they do not cancel these opportunities out. 'Austerity' continues to serve as the principal frame through which the current situation, as well as the possibility of future political and social change, is being imagined. The productive and socially progressive connections forged between the economic and the environmental could still have a purchase in red, as well as green, politics: this might involve, for example, the re-presentation of post-war austerity as the condition of possibility for the founding, rather than the dismantling, of the welfare state (see Sinfield, 1989), or an effort to articulate notions of sustainability (in relation, for example, to models of radical democracy and social justice) to debates about the future of the public sector. These suggestions highlight the fallacy of prescribing in advance what work austerity discourses might or might not do, or, relatedly, of assuming that the rhetorical resources of radicality are themselves set in stone. There are both risks and opportunities here, the significance of which can only be discerned in the context of political struggle. 
In the course of this article I have used the popularization of the 'dig for victory' discourse as a case study to explore some of the assumptions and challenges that inhere in prevailing theorizations of the relationship between historicity and radical subject constitution. I have particularly been concerned to situate 'dig for victory' in the wider discursive formation of 'anti-consumerism', and in debates about the constitution of ethico-political consuming subjects. Through a reflection on the defetishizing commodity histories thought to prompt transformations in the subjects who consume them, I have argued that such moments of conversion depend on the persuasiveness of a particular schema, rather than on the accuracy of the information conveyed or on the subsequent execution of certain expected actions. 'Dig for victory' belongs to an expansive range of stories told about the socialeconomic relations of production, and what is notable here is the historicity of the solutions presented. I have argued that the possibilities that inhere in 'dig for victory' for the conversion of subjects - as well as in other discourses that draw on 'dominant-hegemonic' histories - demonstrate the need to rethink certain longstanding assumptions about the resources to which we might turn in order to construct persuasive narratives which could engage broad constituencies in a politics of environmentalism and anti-consumerism. The task of identifying resources that can hegemonize radical demands is a pressing one. We should not reject the possibility that known, 'dominant-hegemonic' histories might, under certain conditions, serve as a resource for radical projects and for the constitution of agents to pursue those projects.

\section{Endnotes}

${ }^{1}$ See The Digger Archives (2010).

${ }^{2}$ Soper suggests that "[s]uch "agency" would no longer be class specific, but more diffusely exercised - even if in the first instance many of the more rebellious consumers would probably be relatively well off. This kind of counter-consumerist political perspective thus marks a significant departure from earlier critiques of capitalism' (2009: 10).

${ }^{3}$ Thanks to Niles Freebury for introducing me to Michael Pollan's work.

${ }^{4}$ Crouch and Parker are working against the prevailing view of 'heritage' as a politically conservative mode of historical representation (see for example Wright, 1985; Bromley, 1988).

\section{References}


Barnett, C., Cloke, P., Clarke, N. and Malpass, A. (2005) Consuming ethics: articulating the subjects and spaces of ethical consumption. Antipode 37(1): 23-45.

Barnett, C., Littler, J. and Soper, K. (2005) Consumers: agents of change? Soundings 31: 147-160.

Binkley, S. and Littler, J. (2008) Introduction: cultural studies and anti-consumerism: a critical encounter. Cultural Studies 22(5): 519-530.

Bromley, R. (1988) Lost Narratives: Popular Fictions, Politics and Recent History. London: Routledge.

Cameron, D. (2009) The age of austerity. Speech to the Spring Forum. Cheltenham, 26 April.

Cook, I., Evans, J., Griffiths, H., Morris, R., Wrathmell, S. (2007) 'It's more than just what it is': defetishising commodities, expanding fields, mobilising change... Geoforum 38: 1113-1126.

Crouch, D. and Parker, G. (2003) 'Digging-up' utopia? Space, practice and land use heritage. Geoforum 34: 395-408.

Davies, C. (2009) Queen turns corner of palace backyard into an allotment. Guardian, 14 June.

Digging for Victory (2007) Reef Television for UKTV Gardens. Broadcast April-June. Foucault, M. (1975) Film and popular memory. Radical Philosophy 11: 24-29.

Franceschini, A. (2008) Victory Gardens 2008+ website, www.sfvictorygardens.org/about.html, accessed 8 August 2009.

Gilbert, J. (2008) Anticapitalism and Culture: Radical Theory and Popular Politics. Oxford: Berg.

Hall, S. (1996) The problem of ideology: Marxism without guarantees. In: D. Morley and K.-H. Chen (eds) Stuart Hall: Critical Dialogues in Cultural Studies. Abingdon: Oxford.

Harvey, D. (1989) The Condition of Postmodernity: An Enquiry into the Origins of Cultural Change. Oxford: Blackwell.

Hickman, L. (2008a) Dig for victory. Guardian, 30 August.

Hickman, L. (2008b) Dig for thrifty. Guardian website, 16 June, www.guardian.co.uk/environment/ethicallivingblog/2008/jun/16/digforthrifty, accessed 12 July 2009.

Imperial War Museum (2008) Dig for victory teachers' pack. Imperial War Museum website, cwr.iwm.org.uk/upload/package/79/DigForVictory/schools.htm, accessed 12 September 2008.

Jameson, F. (1971) Marxism and Form. Princeton, NJ: Princeton University Press. 
Jameson, F. (1991) Postmodernism, or, The Cultural Logic of Late Capitalism.

London: Verso.

Johnson, R., Chambers, D., Raghuram, P., Tincknell, E. (2004) The Practice of Cultural Studies. London: Sage.

Laclau, E. (1999) Politics, polemics and academics: an interview by Paul Bowman. Parallax 5(2): 93-107.

Laclau, E. and Mouffe, C. (2001) Hegemony and Socialist Strategy. London: Verso.

Littler, J. (2005) Beyond the boycott: anti-consumerism, cultural change and the limits of reflexivity. Cultural Studies 19(2): 227-252.

Littler, J. (2009) Radical Consumption. Maidenhead: Open University Press.

Moor, L. and Littler, J. (2008) Fourth worlds and neo-Fordism: American Apparel and the cultural economy of consumer anxiety. Cultural Studies 22(5): 700-723.

Norman, N. (2007) Bus shelter 2015. Global Cities. London: Tate Modern. JuneAugust.

Pollan, M. (2006) The Omnivore's Dilemma: A Natural History of Four Meals. New York: Penguin.

Popular Memory Group (1982) Popular memory: theory, politics, method. In: R. Johnson, G. McLennan, B. Schwarz, and D. Sutton (eds) Making Histories: Studies in History-Writing and Politics. London: Hutchinson.

Readings, B. (1991) Introducing Lyotard: Art and Politics. London: Routledge.

River Cottage Autumn (2008) Episode 3: Wild food feast. Keo Films for Channel 4. Broadcast 30 October.

Samuel, R. (1989) Introduction: exciting to be English. In R. Samuel (ed.) Patriotism: The Making and Unmaking of British National Identity. Volume I: History and Politics. London: Routledge.

Sassatelli, R. (2009) Representing consumers: contesting claims and agendas. In K. Soper, M. Ryle and L. Thomas (eds) The Politics and Pleasures of Consuming Differently. Basingstoke: Palgrave Macmillan.

Shaw, W. (2009) "Let's hear it for vegetables". Observer, 19 April.

Sinfield, A. (1989) Literature, Politics and Culture in Post-war Britain. Oxford: Basil Blackwell.

Soper, K. (2009) Introduction: the mainstreaming of counter-consumerist concern. In:

K. Soper, M. Ryle and L. Thomas (eds) The Politics and Pleasures of Consuming Differently. Basingstoke: Palgrave Macmillan.

The Digger Archives (2010) website, diggers.org, accessed 3 August 2010.

Weedon, C. (1987) Feminist Practice and Poststructuralist Theory. Oxford: Blackwell. Williams, R. (1975) The Country and the City. St Albans: Paladin. 
Wright, P. (1985) On Living in an Old Country: The National Past in Contemporary Britain. London: Verso.

Zukin, S. (2008) Consuming authenticity: from outposts of difference to means of exclusion. Cultural Studies 22(5): 724-748.

Zweiniger-Bargielowska, I. (2000) Austerity in Britain: Rationing, Controls, and Consumption, 1939-1955. Oxford: Oxford University Press. 